Whooping Crane No nest of the Whooping Crano was located this year. This is hardly to be wondered at, considerine the extent of the territory where they might nest and the foct thet some birdmen believe that there are now less than fifty of these magnificent birds still in existenco. Sight records wero reported to the Provincinl Museum from settled areas during the spring migration and it seems possible that one pair started to nest on a marsh at Furt a La Corne Forest Roserve in May. This marsh was afterwards badly flowded out and no sign of the birds was seen there later in Juno. Anyone having any information regarding the Whooping Crane is asked to communicate with Fred Bard, Curator, Provincial Museur, Regina.

\title{
1945 BIRD RECORDS OF INTEREST IN BRIEF
}

Black Duck A male bird showing no sien of molting, banded July 21 by J. H. Wilson at Leech Lnke, Yorkton. An adult fernalo banded by Stuart Houston at Rousay Like, Yorkton, August 10, and a scoond ferrale, molting and unable to fly, August 22. This is the game duck which largely replacos the malard in Eastern Canada, not often reported for Saskatchewan. PIurages of both sexes the same. May be recognized as a very dark duck with light wing lining. Deop purple wing patch, no white bars.

Hooded Merganser Female banded at Leech Lake July 12. The smallest species of tho "fish-eating" ducks with norrow, saw-like bills. Plunage of fenale greyish-brown, not in cny wy spectacular.

Turkey Vulture Many visitors to Madge Lk ke this yoar repurted seeing large numbers of these huge birds sailing round high

up in the sky.

Cooper's Fawk Five nesting records reported this sumer in the south part of the province. Several sight records. A young bird discovered in a Yorkton duck trap and banded. Cooper"s Hawk is the "chicken hawk" of Eastern Canada and is not cominon on the prairies, but at long intervals appoars in large nurabers. 1945 is apparentiy such a year.

Avocet Three. seen on sancbar in Saskatchewan River above Saskatoon by F. Roy, May 13. "Is this not quite a distance north to find these birds?" asked Mr. Roy. W. Niven, Shoho, ropurts a flock of 20 present on a small alkali slough all sumer. The efss of tho colony reported from Leech Lake, Yorkton, last spring, wore complotely dostroyed by crows and only one Avocet was seen around the lake later in the summer.

Kingfisher F. Roy, Tullis, cot his tirst nosting rocord of the Kingfisher for that listrict this sumer. Nest was situatod in a steep clay bank in a coulee near tho Saskatchewen River.

Crested Flycatchers J. D. Richio, wallwort, Tells us he has know this bird as a nosting species for sevoral yoars.

Tanagers Westorn Tana.Gor. Nost with four oges found at Nipawin by M. G. Stroet. Placed at ond of spruce bough about 20 fect from the ground. 
Lark Sparrow Colony found on hills north of the San, Fort Qu Appelle, by $\mathbb{E}$. M. Callin. This would appear to be the most

northerly point reached by this handsone sparrow. Fomerly confined to S.W. part of the province, but now rapidly extending its range.

Smith's Longspur Seen Sept. I, by W. Niven, Shehu. Mr. Niven knows this rarely recorded longspur as a spring and foll migrant on the fiolds of his fam, six miles out uf sheho.

\section{PLANT $\triangle N D$ INSECT NOTES}

The late spring of 1945 had, of curse, a marked effect on plant Iife. Wild Roses were flowers of July rather than June, afid other flowers of early sumiler overlapped with the first astors and sunflowers. Each fanily of buttorflies was also said to have come on tho wing about two woeks later then usual. Frosts in early June caught the Soskatoun blossons in most places. Most abundant fruit in eastem Saskatchewan was the wild raspberry which nuw seens to have recuvered from the effects of the cry years.

It was good to hoar of yollow Lady's Slippers appearing in mny places in greater abundance than for my soasons. Mrs. E. B. Flock while holidaying at R canville reported finding Lai'y's Slippor plants a foot or more high and bearing huge blossons growing in clump of ten or twelve in the toll grass along the ralroad right of way. To her surprise she learned that the right of way is burned cver every year and yet no harm seoms to come to the urchids. "And, bost of all, they soon to be snfe from overpicking," she wrote.

Two othor chamine native wild flowers, the shooting star, and the Mealy or Birc's-eye Primrose also bloomed in Great profusion in meny meadows this sumer.

In the north country mosquitoes apparontly reached on "ull tine high" for forocity. Wo coubted sore of the tales soeping out, but when M. G. Street, Nipawin, stated that mosquitoes had oven stopnod hir "wirling", wo know thoy must bo renlly bad:

\section{A Wasp EpIsode}

On the Labour Day weok-end, whilo hunting arrow hoads on a sand blow alone the Assinibine, we watched one of the digerer wasps hard at work.

When first noted the was hal just begun tw excovete a vertical shaft in the fine lonso sand. The insect, black and scarcoly half an inch in length, was rapidly digging sinilar to the mannor in which a dof digs for a gopher. Working fron one spot, the sand flow fron between har front feet and was tossed fully three or four inchos bohind her, over the edge of the hole. As the incline becane more steep and sand tumblec to the botton of the hole, she wuld run backwards up the side and bogin a new trouch about an inch fron the rim. 